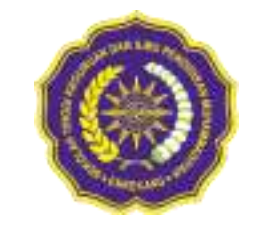

\title{
PENERAPAN TEKNIK REGULASI DIRI (SELF REGULATION) UNTUK MENINGKATKAN KEMANDIRIAN BELAJAR MAHASISWA PROGRAM STUDI BIMBINGAN KONSELING STKIP MUHAMMADIYAH ENREKANG
}

\author{
M. Yasdar; Muliyadi \\ Bimbingan Konseling, STKIP Muhammadiyah Enrekang \\ Email: myasdarbk@gmail.com; muliyadibk@gmail.com
}

\begin{abstract}
ABSTRAK. Penelitian Eksperimen ini dilakukan di Program Studi Bimbingan Konseling dengan subjek penelitian adalah Mahasiswa semester 3 dengan jumlah 10 orang. Masalah dalam penelitian ini adalah Mahasiswa semester 3 mengalami kemandirian belajar yang rendah. Rumusan masalah penelitian ini adalah (1) Bagaimana gambaran kemandirian belajar mahasiswa sebelum penerapan Teknik Regulasi diri di Program Studi Bimbingan Konseling. (2) Bagaimana gambaran pelaksanaan teknik regulasi diri untuk meningkatkan kemandirian belajar Mahasiswa di Program Studi Bimbingan Konseling (3) Bagaimana pengaruh Penerapan Teknik Regulasi diri terhadap kemandirian belajar Mahasiswa di Program Studi Bimbingan Konseling. Pendekatan dalam penelitian ini adalah Penelitian kuantitatif dengan jenis penelitian Pre-Experimental Designs. Teknik pengumpulan data menggunakan wawancara, observasi dan angket. Analisis data menggunakan analisis kuantitatif. Hasil pengujian hipotesis menunjukkan bahwa Teknik Self-Regulation dapat untuk meningkatkan kemandirian belajar. Dengan demikian hasil penelitian ini (1) kemandirian belajar Mahasiswa meningkat setelah diberikan perlakuan berupa latihan regulasi diri meningkat. (2) Penerapan Teknik Self-Regulation memberi pengaruh positif terhadap kemandirian belajar Mahasiswa di Program Studi Bimbingan konseling.
\end{abstract}

Kata kunci : Regulasi Diri, Kemandirian Belajar Mahasiswa, Konseling

\begin{abstract}
Experimental research was done in Program Studi Bimbingan Konseling with research subjects were Student of 3rd semester with a total of 10 people. Problems in this study were Student of 3rd semester experienced a low learning independence. The research problems are (1) How picture of student learning independence before the application of the Regulation Technique himself in Program Studi Bimbingan Konselingkab. Enrekang. (2) How to overview the implementation of selfregulation techniques to increase the independence of student learning in Program Studi Bimbingan Konseling. (3) How does the adoption of Regulation Technique himself against the independence of student learning in Program Studi Bimbingan Konseling. The approach in this research was quantitative research with this type of study Pre-Experimental Designs. The technique of collecting data using interviews, observation and questionnaires. Analysis of data using quantitative analysis. Hypothesis testing results show that the technique can Self-Regulation to improve learning independence. Thus the results of this study (1) increased student learning independence after a given treatment in the form of increased exercise self-regulation. (2) Application of Self-Regulation of Engineering gave a positive influence on student learning independence in Program Studi Bimbingan Konseling.
\end{abstract}

Keywords: Self-Regulation, Independence of Student, Learning Independence \#\# HowToCite\#\#

M. Yasdar; Muliyadi. (2018). Penerapan Teknik Regulasi Diri (self regulation) untuk Meningkatkan Kemandirian Belajar Mahasiswa Program Studi Bimbingan Konseling STKIP Muhammadiyah Enrekang. Edumaspul - Jurnal Pendidikan, 2(2), 50-60 


\section{PENDAHULUAN}

Menurut Sumahamijaya dkk (2003), kemandirian berasal dari kata mandiri yang berarti dalam keadaan dapat berdiri sendiri, tidak bergantung pada orang lain, tapi menggunakan kekuatan sendiri. Menurut Kamus Besar Bahasa Indonesia (1996), kemandirian diartikan sebagai keadaan dapat berdiri sendiri tanpa bergantung kepada orang lain. Dalam proses pembelajaran setiap siswa diarahkan agar menjadi peserta didik yang mandiri, dan untuk menjadi mandiri. Seorang individu harus belajar, sehingga dapat dicapai suatu kemandirian belajar.

Siswa dapat memiliki kemandirian belajar jika memiliki ciriciri diantaranya mampu berfikir kritis, kreatif dan inovatif, tidak mudah terpengaruh oleh pendapat orang lain, tidak merasa rendah diri, terus bekerja dengan penuh ketekunan dan kedisiplinan serta mampu mempertanggung jawabkan tindakannya sendiri (Thoha, 1996). Sedangkan menurut Hoshi (2001, dalam Slameto, 2003) dalam kemandirian belajar siswa bertanggung jawab atas pembuatan keputusan yang berkaitandengan proses belajarnya dan memiliki kemampuan untuk melaksanakan keputusankeputusan tersebut. Dalam proses pemandirian diri siswa guru hanya berfungsi sebagai fasilitator, yaitu guru hanya sebagai pembimbing, misalnya membantu siswa untuk memecahkan suatu masalah bila siswa tersebut menemui kesulitan dalam kemandirian belajar (Benson, 2008). Karena itu guru Bimbingan dan Konseling sekolah mempunyai peran penting dalam pembentukan kemandirian belajar siswa, yaitu melalui layanan bimbingan dan konseling yang membantu individu untuk menjadi insan yang mandiri.

Siswa dikatakan telah memiliki kemandirian belajar apabila ia telah mampu melakukan tugas belajar tanpa ketergantungan pada orang lain. Berdasarkan hasil observasi langsung di lapangan serta wawancara dengan Dosen di Kampus pada tanggal 03 Maret 2017, disebutkan oleh Dosen berbagai macam ciri Mahasiswa yang berada di Program Studi Bimbingan Konseling yang memiliki kemandirian belajar yang rendah. Serta hasil pemberian angket awal yang Sehingga hasil survei awal penulis bahwa kemandirian belajar mahasiswa hanya mencapai $25 \%$ dari total $100 \%$ yang mengalami masalah kemandirian belajar.

Hal ini dapat dilihat dari beberapa gejala yang tampak di lapangan diantaranya adalah kurang percaya diri, masih ada ketergantungan kepada temannya dalam menghadapi masalah belajar, disiplin belajar masih kurang, kurang mengetahui cara belajar yang baik yaitu belajar kalau akan menjelang ujian, malas dalam mengerjakan tugas-tugas yang telah diberikan oleh guru, kurang bisa belajar sendiri, tidak dapat membagi waktu untuk belajar, sering menyontek hasil pekerjaan temannya, tidak mampu berpikir kritis dan kreatif, mudah terpengaruh oleh orang lain, menghindari masalah dalam belajar, tidak mampu memecahkan masalah sendiri tanpa bantuan orang lain, tidak dapat belajar dengan tekun dan penuh kedisiplinan, tidak bertanggung jawab atas pilihan yang di ambil, dan mengerjakan tugas pekerjaan rumah saat mengikuti mata Kuliah yang lain yang mengakibatkan proses belajar mengajar menjadi terganggu. Hal ini menandakan mahasiswa kurang memiliki kemandirian belajar, karena ciri-ciri kemandirian belajar mahasiswa yang telah disebutkan diatas belum tampak pada siswa. 
Apabila keadaan demikian tidak mendapatkan penanganan segera dari pihak pendidik, maka mahasiswa tidak dapat mencapai kemandirian belajar dan dikhawatirkan prestasi mahasiswa akan menurun, sehingga mahasiswa tidak dapat mencapai tujuan yang diharapkan dan keberhasilan belajar tidak dapat dicapai.

Salah satu tugas yang menjadi tanggung jawab layanan bimbingan konseling adalah memajukan, merangsang, dan membimbing proses belajar mahasiswa. Segala usaha yang menuju kearah itu harus direncanakan dan dilaksanakan dengan baik.

Kemampuan memecahkan masalah khususnya meningkatkan kemandirian belajar berkaitan dengan cara belajar mahasiswa, cara mengatur aktivitasnya mahasiswa seperti itu dikenal dengan istilah Self Regulated. Menurut Pintrich (1995:30) Self Regulated adalah cara belajar siswa mengelola kegiatan individu untuk mencapai tujuan tertentu dengan cara pengontrolan perilaku, memotivasi diri sendiri dan menggunakan kognitifnya dalam melakukan tindakan. Secara ringkas, Zimmerman (1989: 22) mengemukakan bahwa dengan Self Regulated siswa dapat diamati sejauhmana partisipasi aktif mereka dalam mengarahkan proses-proses metakognitif, motivasi dan perilakunya disaat mereka melakukan aktivitas.

Hasil peneilitian Pintrich \& DeGroot $(1990 ; 65)$ Van Zile-Tamsen \& Livingston, (1999: 72) mengungkapkan bahwa siswa-siswa yang berprestasi tinggi lebih sering menggunakan strategi self-regulated daripada siswa yang berprestasi rendah.

Memperhatikan beberapa fakta di atas, sangatlah penting untuk menyiapkan siswa dengan berbagai keterampilan, baik intrapersonal maupun interpersonal. Dengan bekal keterampilan-ketrampilan tersebut, diharapkan mahasiswa akan mampu berkompetisi secara sehat dalam dunia yang semakin mengglobal ini. Salah satu keterampilannya adalah keterampilan self-regulated, sehubungan dengan hal tersebut maka peneliti mengguanakan teknik bimbingan berbasis Regulasi diri dalam membantu siswa meningkatkan kemandirian belajar.

\section{Kemandirian Belajar}

Menurut Thoha (1996: 122) bahwa perilaku mandiri adalah suatu kebebasan seseorang dari pengaruh orang lain, yang diartikan kemampuan untuk menemukan sendiri apa yang harus dilakukan, menentukan dan memilih kemungkinan-kemungkinan dari hasil perbuatannya dan akan memecahkan sendiri masalah-masalah yang dihadapi tanpa harus mengharapkan bantuan orang lain.

Menurut Slameto (2002: 43) Belajar merupakan proses dimana siswa yang tidak tahu menjadi tahu, dari tidak paham menjadi paham dan sebagainya. Belajar dalam penelitian ini merupakan unsur yang terkait dengan kemandirian. Sehingga belajar yang dimaksud adalah belajar yang mandiri, yang dapat menjadikan siswa mampu belajar secara mandiri. Dari pengertian kemandirian dan belajar di atas maka dapat disimpulkan bahwa kemandirian belajar adalah aktivitas belajar yang didorong oleh kamauan sendiri, pilihan sendiri, dan mengatur diri untuk mencapai hasil belajar yang optimal serta mampu mempertanggung jawabkantindakannya.

Mahasiswa dikatakan telah mampu belajar secara mandiri apabila ia telah mampu melakukan tugas belajar tanpa ketergantungan pada orang lain. Ciri-ciri pokok siswa mempunyai kemandirian belajar dapat dilihat dari bagaimana ia belajar dengan cara dan teknik sesuai dengan kemampuan 
sendiri serta mampu mengetahui kekurangan diri sendiri. Setiap siswa memiliki gaya dan tipe belajar yang berbeda dengan teman-temannya, hal ini disebabkan bahwa siswa memiliki potensi yang berbeda dengan orang lain. Dalam penelitian ini kemandirian merupakan perilaku yang akan diukur dimana siswa sebagai subjek yang akan diteliti terkait dengan masalah belajar siswa, jadi kemandirian yang dimaksud adalah kemandirian belajar, agar siswa mampu menemukan sendiri apa yang harus dilakukan, memecahkan masalah tanpa bantuan orang lain menentukan dan memilih kemungkinan-kemungkinan dari hasil perilakunya. Kemandirian merupakan faktor pembentuk kemandirian belajar siswa.

Faktor- faktor yang mempengaruhi kemandirian menurut Thoha (1996: 124-125) dapat dibedakan dari dua arah, yakni ;

a. Faktor dari Dalam Faktor dari dalam diri antara lain faktor kematangan usia dan jenis kelamin. Anak semakin tua usia cenderung semakin mandiri. Disamping itu intelegensi seseorang juga berpengaruh terhadap kemandirian seseorang. b. Faktor dari Luar Faktor dari luar yang mempengaruhi kemandirian seseorang adalah: (a) Faktor Kebudayaan Kemandirian dipengaruhi oleh kebudayaan. Masyarakat yang maju dan kompleks tuntutan hidupnya cenderung mendorong tumbuhnya kemandirian dibanding dengan masyarakat yang sederhana.(b) Pengaruh Keluarga Terhadap Anak Pengaruh keluarga terhadap kemandirian anak adalah meliputi aktivitas pendidikan dalam keluarga, kecenderungan cara mendidik anak, cara memberikan penilaian pada anak, bahkan sampai pada cara hidup orangtua berpengaruh terhadap kemandirian anak.
Menurut Ali dan Asrori (2002: 118-119), ada sejumlah faktor yang mempengaruhi pekembangan kemandirian, yaitu: (1) Gen atau keturunan orang tua. Orang tua memiliki sifat kemandirian tinggi sering kali menurunkan anak yang memiliki kemandirian juga. (2) Pola asuh orang tua. Cara orang tua mengasuh atau mendidik anak akan mempengaruhi perkembangan kemandirian anak remajanya. (3)Sistem pendidikan disekolah. Proses pendidikan disekolah yang tidak mengembangkan demokrasi pendidikan dan cenderung menekankan indoktrinasi tanpa argumentasi akan menghambat perkembangan kemandirian remaja/siswa.(4) Sistem kehidupan dimasyarakat. Sistem kehidupan masyarakat yang terlalu menekankan pentingnya hierarki struktur sosial, merasa kurang aman atau mencekam serta kurang menghargai manifestasi potensi remaja dalam kegiatan produktif dapat menghambat kelancaran perkembangan kemandirian siswa/remaja.

Menurut Basri (2000: 53), faktor yang mempengaruhi kemandirian adalah sebagai berikut:

a. Faktor dalam diri sendiri (Endogen). Dengan faktor endogen dimaksudkan adalah semua penngaruh yang bersumber dari dalam dirinya sendiri, seperti keadaan keturunan.

b. Faktor yang terdapat diluar dirinya (Eksogen) Faktor eksogen disebut pula dengan faktor eksternal yaitu semua keadaan atau pengaruh yang berasal dari kuar dirinya, sering pula dinamakan dengan faktor lingkungan. Lingkungan yang dihadapi individu sangat mempengaruhi perkembangan kepribadian seseorang. Yang dimaksud lingkungan disini adalah lingkungan keluarga, masyarakat dan sosialekonomi. 
Dari beberapa pendapat ahli di atas maka dapat disimpulkan bahwa faktor-faktor yang mempengaruhi kemandirian sangat menentukan sekali dalam tercapainya kemandirian seseorang. Begitu pula dengan kemandirian belajar siswa sangat dipengaruhi oleh faktor-faktor yang ada baik faktor yang berasal dari dalam diri sendiri maupun faktor dari luar siswa. Faktor dari diri sendiri misalnya intelligensi, dan keadaan keturunan. Faktor dari luar siswa dapat berasal dari lingkungan keluarga, sekolah, lingkungan sosial ekonomi dan lingkungan masyarakat.

\section{Regulasi Diri (Self-Regulation)}

Para ahli melakukan berbagai penelitian yang berguna, untuk meningkatkan kualitas pendidikan. Salah satunya mengenai teorri Regulasi diri. Berbagai penelitian dilakukan untuk mengupas lebih lanjut mengenai Regulasi diri. Salah satu tokoh yang ikut berkonstribusi besar dalam perkembangan teori Regulasi diri adalah Barry J. Zimmerman.

$$
\text { Zimmerman }
$$

mengatakan bahwa para pakar teori Regulasi diri memandang belajar sebagai suatu proses yang bersifat multidimensi yang mencakup aspek personal (kognitif, dan afektif/emosional), perilaku (behavioral) dan konstektual.

Menurut Susanto (2008: 21) self-regulation dapat digambarkan sebagai sebuah siklus karena feedback dari tingkah laku sebelumnya digunakan untuk membuat penyesuaian dalam usahanya saat ini. Penyesuaian seperti itu diperlukan karena menentukan tahap-tahap untuk mencapai tujuan yang telah ditetapkan (Ismail, I., Busa, Y., \& Tini, T. 2018).. Di samping itu, selfregulated juga merupakan motivasi secara intrinsik dan strategi untuk melakukan sesuatu. Pengertian lain diberikan oleh Corno dan Mandinach bahwa self-regulated adalah suatu usaha untuk memperdalam dan memanipulasi jaringan asosiatif dalam suatu bidang khusus (yang tidak perlu membatasi pada isi akademik), dan memonitor serta meningkatkan proses-proses yang mendalam. Self-regulated mengacu pada perencanaan yang hati-hati dan monitoring terhadap proses-proses kognitif dan afektif yang tercakup dalam penyelesaian tugas-tugas dalam kehidupan sehari-hari.

Bandura mendefinisikan selfregulation sebagai kemampuan untuk mengontrol perilaku mereka sendiri dan juga pekerja keras. Bandura mengajukan 3 (tiga) langkah selfregulation: (1) observasi diri (selfobservation), kita melihat diri kita sendiri, perilaku kita, dan menjaganya; (2) keputusan (judgment), membandingkan apa yang dilihat dengan suatu standar; (3) respon diri (self-response), jika kita lebih baik dalam perbandingan dengan standar kita, kita memberi penghargaan jawaban diri pada diri kita sendiri.

Zimmerman, (2000:34) dalam Self-Regulation : a Literature View (2009:3) memaparkan Self-Regulation sebagai berikut.

Self-Regulation mengacu pada diri yang terintegrasikan pada pikiran, perasaan, dan tindakan yang terencana secara siklus diadaptasi untuk mencapai tujuan pribadi. Zimmerman sendiri menghadirkan perbedaan SelfRegulation Learning (SRL) sebagai penelitian ranah psikologis yang tercermin dalam pergerakan strategi untuk meningkatkan integrasi diri siswa, Meta-Kognitif, Konsep diri (SelfConcept), dan Kontrol Diri (Self_Control).

Berdasarkan pendapat di atas maka Self-Regulation merupakan proses metakognisi yang mengatur proses 
perencanaan, pemantauan/monitoring, dan evaluasi diri dalam aktivitas belajar seperti cara berfikir, pemantauan proses belajar, mengulangi pelajaran agar tercapai tujuan belajar, penguasaan pengetahuan dan keterampilan bagi individu serta pengaturan jadwal belajar guna untuk mencapai tujuan dalam belajar.

\section{Tahapan-tahapan Self-Regulation}

Dalam menerapkan kemampuan mengarahkan diri pada situasi belajar, Zimmerman (1998: 22) mengemukakan suatu model yang berbentuk siklus. berikut:

Model tersebut adalah sebagai

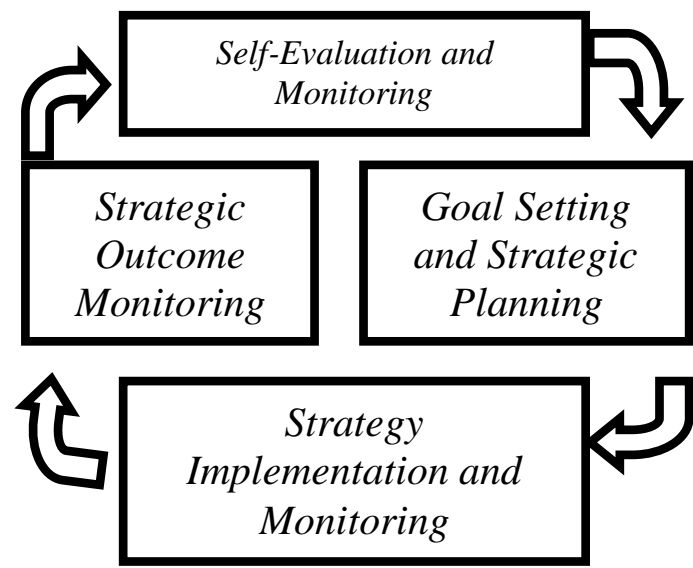

Gambar 2.1: model Self-regulated menurut Zimmerman (1998: 22).

Secara teori tahap-tahap perkembangan Regulasi diri disampaikan Schunk dan Zimmerman (1997: 22), Cleary dan Kitsantas (2000:35) serta Chung (2000: 28) mereka menyebutkan bahwa perkembangan Regulasi diri meliputi empat tahap, yaitu observation, emulation/imitation, self control and Regulasi diri.

Tahap pertama adalah observasi yang diperoleh seorang anak ketika menyaksikan atau mendengarkan seorang model yang memiliki keahlian, seperti seorang siswa yang melihat dan memperhatikan seorang guru yang menulis berulang-ulang dengan frase yang lengkap sebagai suatu kalimat yang sempurna. Ketika siswa mengamati dan memperhatikan guru dalam menuliskan suatu kalimat yang sempurna, siswa memperoleh suatu pengalaman tentang bagaimana suatu kalimat yang sempurna yang harus dibuat.

Tahap kedua yaitu emulasi/imitasi, dalam tahapan ini siswa melakukan keterampilan kognitif maupun motorik secara pribadi, namun masih dengan menerima masukan dan bimbingan dari guru-model. Pengalaman mampu melakukan dengan peniruan ini memberikan siswa suatu perasaan bagaimana suatu proses kognitif harus dilakukan, atau bagaimana suatu keterampilan motorik baru dilaksanakan sehingga terasa secara motorik dan nyata. Kinerja yang telah sama dengan model tidak hanya menyediakan masukan secara sensimotor saja, melainkan hal itu juga memungkinkan siswa untuk mengembangkan proses- proses standar internal tentang kinerja yang benar, yang sangat penting dalam tahapan belajar

Tahap ketiga disebut self control, dimana siswa belajar pada dirinya sendiri dalam rangka membentuk keterampilan kognitif atau motorik sebagai suatu proses yang rutin.

Tahap belajar yang terakhir dikenal dengan Regulasi diri, dimana siswa belajar untuk mengadaptasikan keterampilan kognitif dan motoriknya dengan suatu perubahan lingkungan yang dinamis.

Menurut Zimmerman dan Kisantas dalam Sadikin, (1997: 67) suatu implikasi kunci yang membedakan antara tahap perkembangan keterampilan kognitifmotorik self control dan Regulasi diri adalah kebisaan siswa yang pada awalnya memfokuskan pada aktivitas 
proses ketika siswa mulai berlatih daripada hasil atau produk tujuannya.

Keempat tahapan perkembangan diatas memungkinkan siswa secara sistematis menyesuaikan strategi belajarnya dengan perubahan kondisikondisi personal dan kontekstual. Pandangan yang bersifat multilevel untuk diperolehnya kecakapan melakukan keterampilan belajar ini menekankan perlunya peranan dukungan sosial, motivasi diri dan latihan mengarahkan pada tujuan. Maka secara singkat, analisis perkembangan empat tahap kemampuan Regulasi diri dapat dijelaskan sebagai berikut, dimulai dengan memperoleh pengetahuan tentang keterampilan belajar (observation), dan mencakup penggunaan keterampilan tersebut (imitation), kemudian berusaha menginternalisasikannya (self control), dan mempergunakannya secara adaptif (Regulasi diri).

Dengan melihat pentingnya membantu siswa dalam mengelola ataupun mengatur cara belajarnya secara mandiri dan efektif, salah satu tugas yang menjadi tanggung jawab layanan bimbingan konseling adalah memajukan, merangsang, dan membimbing proses belajar siswa. Segala usaha yang menuju kearah itu harus direncanakan dan dilaksanakan dengan baik. Dengan demikian, memotivasi siswa merupakan salah satu langkah awal yang harus diberikan dalam pelayanan bimbingan dan konseling khususnya bimbingan belajar. Bimbingan dan konseling merupakan salah satu pelayanan pendidikan di sekolah yang lebih menekankan pada aspek perilaku siswa, termasuk belajar pun menjadi ragam bimbingan yang dapat diberikan oleh konselor di sekolah dalam membantu siswanya untuk berkembang. Yusuf dan Nurihsan (2006: 10) menjelaskan bahwa bimbingan yang diberikan dalam bentuk bimbingan akademik atau belajar yaitu bimbingan yang diarahkan untuk membantu individu (siswa) dalam menghadapi dan memecahkan masalahmasalah akademik.

Sejalan dengan pengertian dan tujuan yang sama, sehingga teknik regulasi diri dan bimbingan belajar yang bertujuan untuk membantu siswa atau peserta didik untuk mengetahui dan mengelola cara-cara dan pola belajar yang tepat bagi dirinya guna mampu meningkatkan motivasinya untuk berprestasi. Dengan itu, siswa sangatlah perlu untuk latihkan Regulasi diri guna untuk proses belajarnya yang lebih baik.

\section{METODE PENELITIAN}

Penelitian yang digunakan oleh peneliti adalah pendekatan kuantitatif dengan metode penelitian eksperimen "Eksperimen adalah suatu cara untuk mencari hubungan sebab akibat (hubungan kausal) antara dua faktor yang sengaja ditimbulkan oleh peneliti dengan mengeliminisasi atau mengurangi atau menyisihkan faktorfaktor lain yang bisa mengganggu" Arikunto, (2006: 34).

Dalam penelitian, desain ini dilakukan untuk membandingkan hasil pretest dengan hasil posttest.

Desain yang digunakan dapat digambarkan sebagai berikut:

\section{$\begin{array}{lll}\mathrm{O}_{1} & \mathrm{X} & \mathrm{O}_{2}\end{array}$}

Gambar: 3.1 Desain penelitian ( Sugiono, 1999:160)

Keterangan :

$\mathrm{O}_{1}$ : Pengukuran pertama(awal) sebelum subjek diberi perlakuan $\mathrm{X}$ : Treatmen atau perlakuan (Regulasi diri)

$\mathrm{O}_{2}$ : Pengukuran kedua setelah subjek diberi perlakuan 
Prosedur pelaksanaan penelitian mulai dari tahap perencanaan, pretest, pemberian Regulasi diri dan posttest, adapun alur pengembanganya sebagai berikut:

1. Identifikasi subjek

2. Pelaksanaan pre-test terhadap subjek eksperimen

3. Pemberian Regulasi diri terhadap subjek eksperimen.

4. Pelaksanaan post-test terhadap subjek eksperimen

Untuk kebutuhan analisis data, dicari selisih score antara pre-test dan post-test untuk subjek eksperimen. Nilai selisih (gap score) inilah yang dibandingkan dengan uji wilcoxon.

\section{HASIL DAN PEMBAHASAN}

Berdasarkan hasil penelitian dengan menggunakan Pre-eksperimen yang dilakukan terhadap 10 siswa secara kelompok mengenai kemandirian dalam belajar di Program Studi Bimbingan konseling, sebelum dan sesudah perlakuan berupa teknik Regulasi diri, maka berikut ini akan dianalisis dengan menggunakan analisis statistik deskriptif untuk menggambarkan tingkat kemandirian dalam belajar siswa sebelum (pretest) dan setelah (posttest) diberi perlakuan teknik regulasi diri, dan analisis kuantitatif untuk menguji hipotesis pada penelitian tentang adanya perbedaan tingkat kemandirian dalam belajar siswa sebelum dan setelah diberi perlakuan berupa latihan regulasi diri. Berikut di jelaskan gambaran tingkat kemandirian belajar siswa sebelum dan sesuadah pemberian latihan regulasi diri.

\section{Gambaran Tingkat Kemandirian dalam Belajar mahasiswa Sebelum}

\section{Dan Setelah Diberikan latihan regulasi diri}

Tabel 4.1: Data Tingkat Kemandirian

Belajar Mahasiswa Sebelum

(Pretest) Dan Setelah (Posttest)

Diberikan Teknik Regulasi diri di

Program Studi Bimbingan

Konseling.

\begin{tabular}{|l|l|l|l|l|l|}
\hline \multirow{2}{*}{ Interval } & \multirow{2}{*}{ Kategori } & \multicolumn{2}{|c|}{ Pretest } & \multicolumn{2}{c|}{ Posttest } \\
\cline { 3 - 6 } & & $\mathrm{F}$ & $\mathrm{P}$ & $\mathrm{F}$ & $\mathrm{P}$ \\
\hline $\begin{array}{l}178- \\
211\end{array}$ & Sangat tinggi & 0 & $0 \%$ & 0 & $0 \%$ \\
\hline $\begin{array}{l}144- \\
174\end{array}$ & Tinggi & 0 & $0 \%$ & 5 & $50 \%$ \\
\hline $\begin{array}{l}110- \\
143\end{array}$ & Sedang & 6 & $60 \%$ & 3 & $30 \%$ \\
\hline $76-109$ & Rendah & 4 & $40 \%$ & 2 & $20 \%$ \\
\hline $42-75$ & Sangat rendah & 0 & $0 \%$ & 0 & $0 \%$ \\
\hline \multicolumn{2}{|c|}{ Jumlah } & 10 & $\mathbf{1 0 0} \%$ & $\mathbf{1 0}$ & $\mathbf{1 0 0 \%}$ \\
\hline
\end{tabular}

Sumber : Hasil Angket Penelitian

Tabel di atas menunjukkan bahwa sebelum diberikan perlakuan berupa teknik Regulasi diri, tingkat kemandirian belajar siswa di Program Studi Bimbingan Konseling yaitu sebanyak 6 responden ( $60 \%$ ) berada pada kategori sedang, kemudian kategori rendah sebanyak 4 responden (40 \%). Hal ini berarti bahwa tingkat kemandirian belajar siswa di Program Studi Bimbingan Konseling berada pada kategori sedang.

Setelah diberikan teknik regulasi diri sebanyak 6 sesi, tingkat kemandirian dalam belajar siswa di Program Studi Bimbingan Konseling mengalami peningkatan. Hal ini dapat dilihat dari tingkat kemandirian belajar siswa yang berada dalam kategori rendah 2 responden (20\%), kategori sedang 3 responden $(30 \%)$, dan kategori tinggi sebanyak 5 responden $(50 \%)$. 
Dengan kemandirian belajar, selain memperoleh kecakapan juga dapat mengembangkan daya kognitif yang tinggi. Ini disebabkan karena anak terbiasa dalam menghadapi tugas serta mencari pemecahan sendiri dengan menggali sumber-sumber belajar yang ada dan berdiskusi dengan teman kelompoknya dalam menghadapi kesulitan belajarnya.

Menurut Schunk dan
Zimmerman (1998) terdapat tiga phase utama dalam siklus Kemandirian belajar SRL (Self regulated Learning) yaitu: merancang belajar, memantau kemajuan belajar selama menerapkan rancangan, dan mengevaluasi hasil belajar secara lengkap. Serupa dengan Schunk dan Zimmerman (1998). Kemandirian belajar SRL (Self regulated Learning) merupakan siklus kegiatan kognitif yang rekursif (berulang-ulang) yang memuat kegiatan: menganalisis tugas; memilih, mengadopsi, atau menemukan pendekatan strategi untuk mencapai tujuan tugas; dan memantau hasil dari strategi yang telah dilaksanakan.

Berdasarkan hasil penelitian terhadap 10 subjek penelitian menunjukkan bahwa tingkat kemandirian belajar sebelum diberikan teknik Regulasi diri berada pada kategori rendah. Adapun gejala rendahnya kemandirian belajar yang dialami oleh siswa di Program Studi Bimbingan Konseling adalah siswa kurang mampu untuk mandiri dalam belajar, banyak bersifat serba pasif.

Hasil peneilitian Pintrich \& DeGroot (1990; 65) VanZile-Tamsen \& Livingston, (1999: 72) mengungkapkan bahwa siswa-siswa yang berprestasi tinggi lebih sering menggunakan strategi self-regulated daripada siswa yang berprestasi rendah. Hal tersebut didukung hasil penelitian Zimmerman dan Schunk (Zimmerman, 1990: 16) yang menunjukkan bahwa siswa yang memperoleh prestasi belajar yang tinggi adalah siswa yang mampu melakukan perencanaan dan menentukan tujuan hidup yang akan dicapai.

Memperhatikan beberapa fakta di atas, sangatlah penting untuk menyiapkan siswa dengan berbagai keterampilan, baik intrapersonal maupun interpersonal.

Pada akhir penelitian atau sesudah pemberian perlakuan, ditemukan perbedaan sebelum dan setelah penerapan Latihan Regulasi diri. Perubahan-perubahan tersebut dapat pula dilihat dari hasil observasi yang dilakukan selama penelitian. Hal ini dapat terlihat pada hasil analisis persentase tiap pertemuan secara individual yang semakin meningkat. Pada awal-awal pertemuan respon siswa masih sangat rendah, di mana terlihat siswa hanya menempati kategori sangat rendah sebanyak 3 Mahasiswa, rendah sebanyak 2 Mahasiswa, dan sedang 4 Mahasiswa. Selanjutnya respon siswa menjadi lebih meningkat pada pertemuan keempat, siswa tidak lagi menempati kategori sangat rendah tetapi meningkat ke kategori rendah sebanyak 2 Mahasiswa, sedang 7 Mahasiswa, dan tinggi 1 Mahasiswa. Selanjutnya pada pertemuan kelima dan keenam mahasiswa tinggal menempati kategori, tinggi, dan sangat tinggi, di mana jumlah yang menempati kategorikategori tersebut meningkat dari pertemuan kelima ke pertemuan keenam. Berdasarkan hasil penelitian di atas, maka latihan regulasi diri mampu meningkatkan kemandirian belajar Mahasiswa.

\section{KESIMPULAN}

1. Tingkat kemandirian belajar siswa di Program Studi Bimbingan Konseling sebelum diberikan perlakuan berupa teknik Regulasi diri (Regulasi diri) 
berada pada, kategori sedang, sesudah perlakuan berada pada kategori tinggi.

2. Teknik Regulasi diri yang dapat meningkatkan kemandirian belajar karena setelah siswa dilatih Regulasi diri, siswa dapat mengatur pencapaian dan aksi mereka sendiri, menentukan target, mengevaluasi aksi, dan memberi penghargaan diri.

3. Teknik Latihan Regulasi diri berpengaruh positif dan signifikan dalam meningkatnya kemandirian dalam belajar siswa, dimana terjadi peningkatan kemandirian belajar siswa setelah memperoleh teknik regulasi diri di Program Studi Bimbingan Konseling

\section{DAFTAR PUSTAKA}

[1] Ali, dan Asrori,. 2002. Psikologi Remaja Perkembangan Peserta Didik. Bumi Aksara.

[2] Anung, 2000. Belajar Mandiri. Jakarta: Seamolec

[3] Arikunto, 1998. Prosedur Penelitian. Jakarta: Rineka Cipta

[4] Basri. 2000. Remaja Berkualitas, Problematika Remaja dan solusinya. Yogyakarta : Pustaka Pelajar

[5] Benson. 2008. Pemecahan masalah siswa secara mandiri. Jakarta: EGC

[6] Brewer. 2006. Teori Kemandirian. Online.

(teori-

kemandirian@blogspot.com di akses pada tanggal 4 September 2014)

[7] Chaplin. 2006. Kamus Lengkap Psikologi. Jakarta: Raja Grafindo Persada.

[8] Corno L. \& Randi, J. 1999. SelfRegulated Learning. (http//www.personal.self.htm diakses pada tanggal 4 Desember 2014).
[9] Djamarah. (2002). Teori Motivasi, edisi 2 (ed-2), Jakarta : PT. Bumi Aksara

[10] Hargis, J. 1988. The SelfRegulated Learner Advantage: Learning Science on the Internet. (http:/www.jhargis.co. diakses pada tanggal 20 desember 2014)

[11] Hasbahuddin, Dkk. 2009. Efektifitas Self-Regulated Learning Dalam Meningkatkan Prestasi Belajar Mahasiswa Psikologi Pendidikan Dan Bimbingan. Makassar: Fakultas Ilmu Pendidikan.

[12] Hadi, S.2000. Statistik jilid 1 dan 2, Yogyakarta: Andi Offset

[13] Hariwijaya, M. dan Djaelani, B. M. 2008. Teknik Menulis Skripsi Dan Tesis Disertai Contoh Proposal Skripsi. Yogyakarta: Hangar kreator.

[14] Holstein, Herman. (1980). Murid belajar mandiri. Bandung: Remaja Karya CV

[15] Ismail, I., Busa, Y., \& Tini, T. (2018). Parental involvement in fostering the character of children's discipline at elementary school. Jurnal Pendidikan Progresif, 8(2), 53-67.

[16] Kartawijaya, \& Kay Kuswanto. 2004. Artikel Tentang "Mendidik Anak Untuk Mandiri”.)( http://www.geoogle.com.epsikologi. Diakses pada tanggal 20 desember 2014)

[17] Lestariningrum, 2003. Pengaruh Layanan Bimbingan Belajar Terhadap Kemandirian Belajar siswa Kelas VI SD N Delik Rejo 01-02 Semarang Tahun Pelajaran 2002/2003. Skripsi. Semarang: Unnes

[18] Mc. Millan, J.H \& Schumacher. 1993. Research in Education: a Conceptual Introduction. Third 
Edition. New York : Harpeen Collins: College Publisher

[19] Nurihsan. \& Sudianto. (2005). Manajemen Bimbingan dan Konseling Di SMP kurikulum 2004. Jakarta : Grasindo

[20] Prayitno. 1995. Layanan Bimbingan dan Konseling Kelompok. Ghalia Indonesia

[21] Pintrich. (1995). Promotion of Self

RegulatedLearning.http://dwb.unl. edu/Book/CH09/Chapter09w.html. Diakses 6 maret 2014.

[22] Pintrich, P.R., \& De Groot, E.V. (1990). Motivational and self regulated learning components of classroom academic performance. Journal of Educatinal Psychology, 82 (1), 33-40

[23] Romlah, 2001. Bimbingan Kelompok, Malang: UNM

[24] Schunk dan Zimmerman (1998) kemandirian belajar siswa. (Online).http://www.geoogle.com. e-psikologi.

[25] Seligman, L \& Reichenberg, LW. 2010. Teori konseling dan psikoterapi.Upper Saddle River, NJ: Pearson.

[26] Siswandi. 2009. Kemandirian Belajar.

(Online).(http://nazwadzulfa.word press.com, diakses 20 Desember 2014).

[27] Slameto. 2003. Belajar dan Faktor-Faktor Yang Mempengaruhinya, Jakarta: Rineka Cipta

[28] Sugiono. 2008. Metode Penelitian Kuantitatif Kualitataif dan $R \& D$. Bandung:Alfabet.

[29] Sukardi, 1996. Pengantar Pelaksanaan Program BK di sekolah. Jakarta: Rineka Cipta
[30] Surya, 2000. Kiat Mengajak Anak Belajar dan Berprestasi. Jakarta. PT. Gramedia

[31] Thoha, 1996. Kapita Selekta Pendidikan. Yogyakarta: Pustaka Pelajar

[32] Tiro, M.A. 2004. Dasar- dasar Statistik. Ujung Pandang

[33] Yusuf. \& Nurihsan. (2005). Landasan bimbingan dan Konseling.Bandung : Program Pascasarjana Universitas Pendidikan Indonesia dan Remaja Rosdakarya.

[34] Zimmerman, B. J. (1989). A Social Cognitive View of SelfRegulated Academic Learning. Journal of Educational Psychology, 81, 329-339.

[35] Zimmerman, B. J. \& Pons, M. M (1988). Construct Validation of A Strategy Model of Student SelfRegulated Laearning. Journal of Educational Psychology, 80, 284290.s 